\title{
The Application of "The Mystery Guest Game" to enhance the Students English Verbal Communication of Grade X-1 of SMA Pabelan in 2010/2011
}

\author{
Agus Sudiyatno \\ SMAN 1 Pabelan \\ Desa Semowo, Pabelan, Kabupaten Semarang \\ sudiyatnoagus@yahoo.co.id
}

\begin{abstract}
This classroom action research was carried out due to the students' low achievement in the verbal performance. There was a question whether the application of "The Mystery Guest Game" could increase the students' skill in communication. The purpose of this research was (1) to increase the students' skill in their verbal communication, (2) to increase their interests in learning the language. After having finished the research for 2 cycles, the result was gained as follows. At the cycle I, the students' performance showed 41 sentences during 21 minutes. It means in 21 minutes students could ask 41 recorded questions during the class observation. The rate is 1.95. At the second week the rate showed 2.58 which show an increase of $32 \%$. At the third week, the rate shows an increase of $83 \%$ compared to the second performance. At the cycle II, the increase of student's performance showed $15 \%$ or of 5.45 compared to the third week of the cycle I. The students' performance at the second week increases to 6.95 or $27.6 \%$. At the third week the students performance increase to 160 sentences or $4.60 \%$ compared to the second week. The students' responses based on the questionnaires show that $85 \%$ students were interested in the teaching and the game is the main reason. The percentage of performance was $77 \%$. Those evidences showed that "The Mystery Guest Game" increased students' interest in English during the teaching game.
\end{abstract}

Keywords: "The Mystery Guest Game”, verbal, enthusiasm

\section{Abstrak}

Penelitian tindakan kelas ini dilaksanakan karena prestasi rendah siswa dalam performa verbal. Ada sebuah pertanyaan apakah penerapan "permainan tamu misterius" dapat meningkatkan ketrampilan siswa dalam berkomunikasi. Tujuan penelitian ini (1) untuk meningkatkan ketrampilan siswa dalam 
komunikasi verbalnya, (2) untuk meningkatkan minat mereka dalam belajar bahasa. Setelah menyelesaikan penelitian selam 2 siklus, diperoleh hasil sebagai berikut. Pada siklus I, performa siswa menghasilkan 41 kalimat selama 21 menit. Ini berarti dalam 21 menit siswa dapat bertanya 41 catatan pertanyaan selama pengamatan kelas. Nilainya sebesar 1, 95. Pada minggu kedua nilainya menjadi 2.58 yang mana menunjukan peningkatan sebesar 32 $\%$. Pada minggu ketiga, nilainya menunjukan peningkatan sebesar $83 \%$ dibandingkan dengan penampilan pertama. Pada siklus II, peningkatan performa siswa sebesar $15 \%$ atau 5.45 dibanding dengan minggu ketiga dari siklus I. Performa siswa pada minggu kedua naik menjadi 6.95 atau $27.6 \%$. pada minggu ketiga performa siswa naik menjadi 160 kalimat atau $4.60 \%$ dibandingkan dengan minggu kedua. Respon siswa berdasarkan kuisioner nampak bahwa $85 \%$ siswa tertarik dengan pengajaran dan permainannya adalah alasan utama. Posentase performa sebesar 77\%. Fakta tersebut menunjukkan bahwa "permainan tamu misterius" menaikan minat siswa terhadap bahasa Inggris selama permainan pengajaran tersebut.

Kata Kunci: “Permainan Tamu Misterius”, Verbal, Antusiasme

\section{Introduction}

It is a public secret that graduations of high school students in Indonesia have low proficiency in spoken English though on the level of casual dialogues. This case may be traced back to many factors underlies it. First, the National suggested syllabus exposes few kinds of finding such as: (a) the limited classrom teaching hours on the syllabus, 4 hours each week, is still distributed for other skills, listening, reading and writing. Although there is a flexibility of teaching topics in arranging teaching items in the syllabus, the four skils can not be left; (b) at the National Examination, the major material being tested is reading with 35 items while listening is just 15 items. Writing and speaking can not be found on the test. This may cause English teachers focus on preparing the final examination by drilling the reading and listening exercise. Thus, the success of study is based on "the items drilling". How excellent the students' proficiency is, if they get failed in the National 
Examination they can not be considered "successful" either. This thought may influence the way of thinking for almost English teachers, at least weaken their teaching motivation.

Second, it was found out over the past experience that teachers having insufficient techniques of teaching prefer using textbooks. They thought that textbook teaching was more practical and saving time. Such kind of attitudes may mislead the concept of teaching language : teachers tend to teach the language not teaching students to communicate.

Third, another problem is the students' motivation. Students who are highly motivated tend to learn more and initiate to acquire the language better than the less motivated ones

Language teaching and learning theory says that the students' learning will be successful if it is run in the relaxing situation. It means the classes are free from stress, anxieties and bullying. As a result, students as members of the class community will feel secured to express their learning competencies (Krashen in Brown, 2007: 323). Hence, teaching techniques using games played on televisions such as Tak-tik-boom, Tebak lagu, Berpacu bersama Melodi, Pesona Tiga Belas or ,Satu Melawan Seratus have the positive aspects of creativity, challenging, and increasing the solidarity among friends. This activity will reduce tension and stress, in the other way round encourage the spirit of members of the team during playing the game.

"The Mystery Guest Game" is taken from the television game. It is perfomed in group of 2, 3 or more. The duties of group members are to collect data or information of certain people or subjects. The members have to get the information by asking the referent. The subject being asked in the game is called "the mystery guest" and the referents are the students who know all data of the mystery guest. The referents have only one tone answer, 
"yes", or "no". "Yes" if the expected answer agrees with the available data and "no" if the answer does not match with the available data.

Based on the above description, the research focuses on the efectivity of using "The Mystery Guest Game" to enhance students abilities in the English classsroom and the impact of the game on students interest and classroom atmosphere.

\section{Research method}

This action research was conducted at SMA Negeri 1 Pabelan, Kab Semarang, grade X-1 Semester 1 2010/2011. It was started in September 2010 and ended in December 2010. The research subject was 22 students (13 males and 9 females).

The data were collected through class observation, questionaires and the students verbal performance. This action research was conducted in two cycles and each cycle was followed by sequence activities, mainly planning, action, class observation and reflection.

The outlook feature of the game looked like "Pesona Tiga Belas" with a little modification where a group of panelists asked several questions in a limited time. When the alarm clock rang, the panelists stopped asking and guessed the hiding person. On this report, such game was called "The Mystery Guest Game” as shown on the title of this paper.

The questionaire sheet had ten questions to gain the students responses. Five questions asked students opinions about their interest, teacher's teaching techniques and instruction, classroom athmosphere and other aspects of the classroom teaching. The other two questions asked students problems during the teaching hours, and the rest of the questions were about students' instructional motivation. The questionaires mainly 
required students free opinions, thus the questions were "Yes/No" and openended ones.

\section{Discussion and findings}

\section{Cycle 1}

\section{Teaching preparation}

The topic of this cycle was the family tree.The mystery guest for cycle 1 was from the following reading text slightly adopted from lembaga bahasa LIA, entitles All About People, Basic I. It excerpts as follows:

Hi! I'd like to tell you about my family. Let me start with my grand parents: they are $\underline{\text { Robert }}$ and Betty. My granpa is 95 and grandma is 94 years old.They live together with us in a big house called the Roberts. It is situated in the country side.

Our grandparents have two sons, my uncle and my father. My uncle who is two years older than my father is named Paul. He got married with Sandra in 1987.

They have a daughter and a son. They are Michael and Michel. Michael is a firefighter and his sister is a nurse.

My father's name is David, my mother is Mary. They have two sons, my brother Bob and Me. $\underline{B o b}$ is 44 years old. He is an accountant. $\underline{\text { Sally }}$ is my sister in law. I'm two years younger than him. My name is John Stanley. My friends call me Stanley. I've been working as postman since 1990. Susana, my wife is an English teacher in the nearest elementary school. She's been teaching for almost 15 years.

We have two daughters and two sons. Our first daughter is 16 years old. Her name is Alicia. Jimmy is two years younger than Alicia. Our second daughter, inda is about twelve years old. $\underline{\text { Peter }}$, our second son is 10 years old. He is the naughtiest. Among of them. However, we love him so. We are so happy and proud of our extended family and we will keep it that way.

There were several activities for teaching preparation, such as planning teaching-learning process, deciding the topic, preparing the lesson plans, 
providing teaching aids, developing teaching scenes such as making small group works (3 or 4 persons), explaining its respective job description, game's procedures, scoring system, preparing observation team work and preparing observation instrument.

Before doing the class observation, there were several teaching learning processes comprising clinical evaluation to students' grammars, correcting their questions, pronunciation, techniques of drawing conclusion and description of the "mystery guest" data.

After 3 times of clinical evaluation, the performance test was carried out. The researcher was assisted by other teachers to take pictures using a handy camera and conduct observation. The result of observation was written in the scoring sheet.

The similar topic was presented by each group in turns. The presentation was observed, recorded, and scored. The notes included students' activities in their groups, the length of time, and students' interest during presentation.

\section{Classroom activities}

In the early teaching, the teacher introduced a short passage about a certain family. Students were required to listen to the text being dictated. The text exposed the family members including their names and its relationship. After the first listening, the teacher distributed the blank family tree diagram. Then the teacher repeated the dictation of the text, while the students filled up the family tree diagram. After finishing the job, the teacher gave students the text to check the answer. The text showed more or less similar to the above example in Basic I. 
Those activities were followed by teacher's questions asking about the family's relationship, their names, ages, as well as their jobs. The last step students were instructed to read the text in detail.

The questions were: Is it male? Is he/she the grandpa's age? Is he/she David's age? Is he/she Stanley's age? Is he/she the school student's age? Is he/she retired? Is he/she public servant? Is he/she a doctor?

The key success of catching the mystery guest is by asking general to more specific questions, for examples: asking the ages, followed by the professions/jobs, the family relationship and finally "catching guest" by asking the closing question. "Is he/she ..........? (mentioning the name)"

After finishing the reading activities, "The Mystery Guest Game" would start. The students had to make grouping, act out as the referent or to be the panel. The mystery guest was taken from the previous reading text they had just learned. The referents' duties just gave two short answers while the maximum roles were on the hands of the groups of speakers. On that time they were free to ask as many questions as they could to catch "the mystery guest" in a limited time. Their performances, then, were observed and recorded.

In the end, the questionnaires were distributed to know how the students' feelings and comment. At the end of cycle I, there was an evaluation.

\section{Evaluation of Cycle 1}

The scores on the observation sheet shows how students' reactions from one game to the other games. The indicators comprises three kinds of category: active, fair, poor. Those indicators have close relationship with the number of questions the students ask. "Active" means that students ask more 
than 4 questions in a minute, "fair" is between $3-4$, and "poor" is $0-2$ questions.

On the first and second week, there were not any students asking more than 4 questions per minute. On the third week there were 2 students asking more than 4 , the rest of them, the majority, only asking $1-2$ questions. On the teaching learning process of the second week, there were 7 students on the fair group who asked 3-4 questions, while the passive group decreased to 12 students. On the third week there were 2 students belong to the active group, 6 students on the fair group, and the rest, 14 students on the passive group. The result of their performance can be observed on table 1 .

Table 1

The result of observation for cycle 1

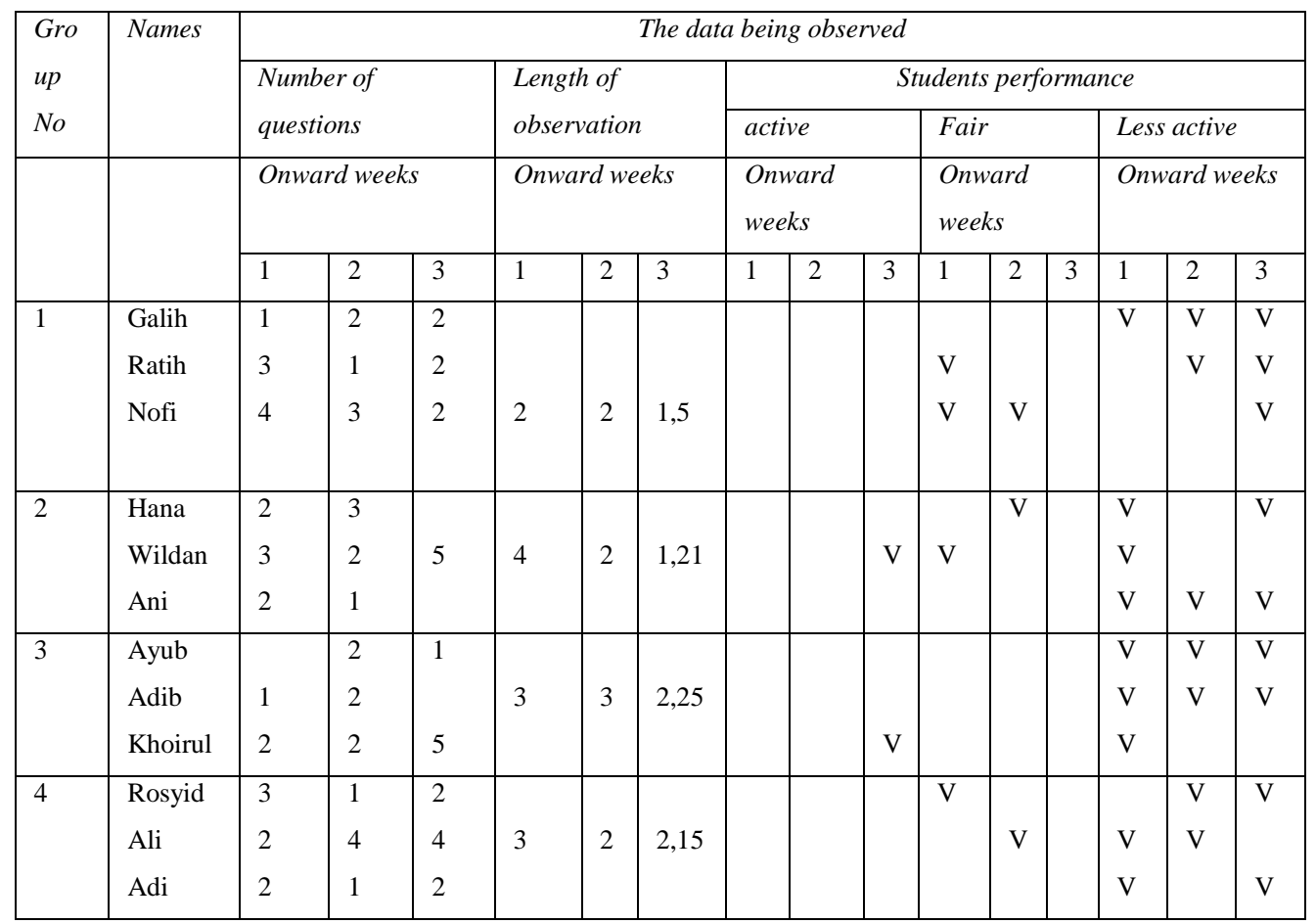




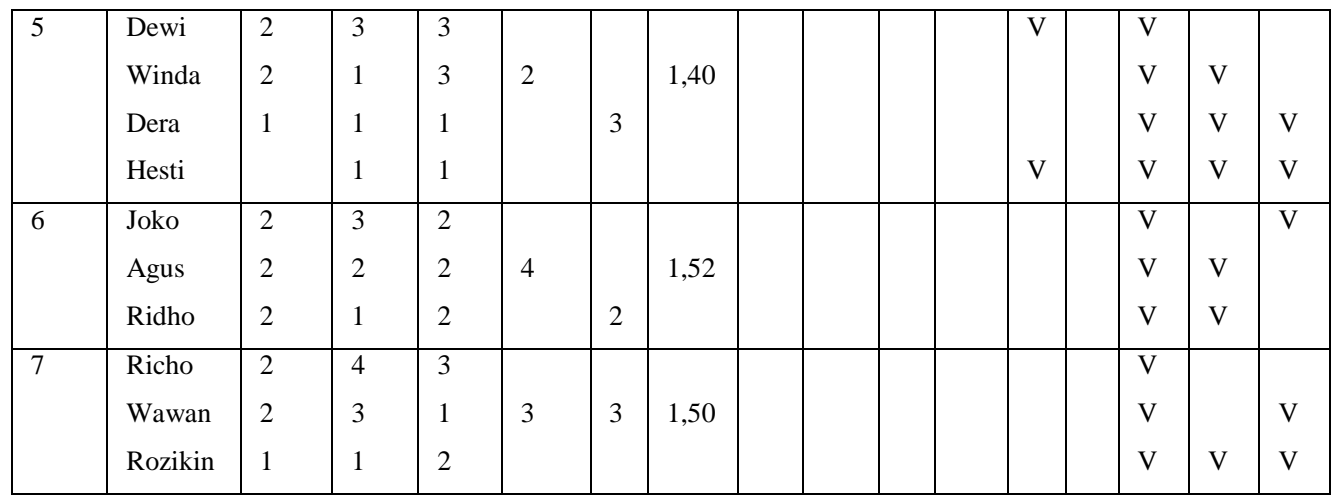

One of the weaknesses of the first cycle was too many people joined in one group, while the time location provided to ask questions was very limited. In another case, the management of grouping and its job description was not good, hence, one student dominated the group.

\section{Cycle 2}

\section{Teaching preparation}

Based on the weakness of students' performances in Cycle 1, there were some improvements for teaching steps. These improvements included not only the limiting members of each group, the time duration for students' performances but also giving more detailed job description for the members of group.

The game's rules for cycle 2 presentation were also different: (1) Every group had one minute to carry out their presentation; (2) Every group had chances 3 times for trial presentation using their hand out, after that they had to practice without it; (3) "The mystery guest" should live in one of countries in Asia, Europe, America, or Africa such as enlisted on the table below; (4) The questions should address to the names of continents, 
nationalities, or languages; (5) The winner was the group that its members asked most questions in one minute

Table 2

The identities of mystery guests

\begin{tabular}{|l|c|c|c|}
\hline \multicolumn{1}{|c|}{ Names } & Countries & Nationalities & Languages \\
\hline Siti Nur Haliza & Malaysia & Malaysian & Malay \\
\hline Sasuhe & Japan & Japanese & Japanese \\
\hline Sahrur khan & India & Indian & Indian \\
\hline Lin Piao & China & Chinese & Chinese \\
\hline Hitler & Germany & German & German \\
\hline John, the Pope & Italy & Italian & Italian \\
\hline Sarkozi & France & French & French \\
\hline David Villa & Spain & Spanish & Spanish \\
\hline Barrack Obama & USA & American & English \\
\hline Eric Estrada & Mexico & Mexican & Spanish \\
\hline Messi & Argentina & Argentine & Spanish \\
\hline Ronaldo & Brazil & Brazilian & Portuguese \\
\hline Husni Mubarok & Egypt & Egyptian & Arabic \\
\hline Nelson Mandela & South & African & English \\
\hline Moamar Ghadafi & Libya & Libyan & Arabic/Italian \\
\hline Kahlil & Nigeria & African & Arabic \\
\hline
\end{tabular}

\section{Teaching activities and evaluation}

The result of students' performances in Cycle 2 can be overlooked on table 3 below.

It was found out that 16 out of 22 students could ask more than 4 questions in one minute. It means that their performances belonged to "the active" category. If all questions were totalled in numbers, the questions were 
accumulated to 120 sentences or on average means 5,45 (more than 5 sentences) could be responded by the group members.

In addition, on the first meeting, 6 students fell on "the fair" category, but no one fell on "the poor" one. In other words, $28 \%$ students did not yet respond in the optimum way.

On the second week almost all students could ask more than 4 questions in one minute (21 students or 95\%). The whole sentences were counted totally to 153 . It means that one student could ask 6,95 or between 6 to 7 sentences per minute. There was only one student remained less active on the second week. It was Adi.

Table 3

Student's performance

\begin{tabular}{|c|c|c|c|c|c|c|c|c|c|c|c|c|c|}
\hline \multirow{5}{*}{$\begin{array}{l}\text { Group } \\
\text { Numbers }\end{array}$} & \multirow{5}{*}{$\begin{array}{l}\text { Names of } \\
\text { members }\end{array}$} & & & & & & & & & & & & \\
\hline & & \multirow{2}{*}{\multicolumn{3}{|c|}{$\begin{array}{l}\text { Number of } \\
\text { questions }\end{array}$}} & \multicolumn{9}{|c|}{ Performances } \\
\hline & & & & & \multicolumn{3}{|c|}{$\begin{array}{l}\text { Active } \\
>4\end{array}$} & \multicolumn{3}{|c|}{$\begin{array}{l}\text { Fair } \\
3-4\end{array}$} & \multicolumn{3}{|c|}{$\begin{array}{l}\text { Poor } \\
0-2\end{array}$} \\
\hline & & \multicolumn{3}{|c|}{ Onward week } & \multicolumn{3}{|c|}{ Onward week } & \multicolumn{3}{|c|}{ Onward week } & \multicolumn{3}{|c|}{ Onward week } \\
\hline & & 1 & 2 & 3 & 1 & 2 & 3 & 1 & 2 & 3 & 1 & 2 & 3 \\
\hline 1 & $\begin{array}{l}\text { Fatkur } \\
\text { Galih }\end{array}$ & $\begin{array}{l}7 \\
6\end{array}$ & $\begin{array}{l}5 \\
5\end{array}$ & $\begin{array}{l}4 \\
11\end{array}$ & $\begin{array}{l}\mathrm{V} \\
\mathrm{V}\end{array}$ & $\begin{array}{l}\mathrm{V} \\
\mathrm{V}\end{array}$ & $\begin{array}{r}-\mathrm{V} \\
\mathrm{V}\end{array}$ & & & $\mathrm{V}$ & & & \\
\hline 2 & $\begin{array}{l}\text { Wildan } \\
\text { Hana }\end{array}$ & $\begin{array}{l}7 \\
3\end{array}$ & $\begin{array}{l}7 \\
9\end{array}$ & $\begin{array}{l}5 \\
4\end{array}$ & $\begin{array}{l}\mathrm{V} \\
-\end{array}$ & $\begin{array}{l}\text { V } \\
\text { V }\end{array}$ & $\begin{array}{l}\mathrm{V}- \\
-\end{array}$ & V & & V & & & \\
\hline 3 & $\begin{array}{l}\text { Adib } \\
\text { Khoirul }\end{array}$ & $\begin{array}{l}4 \\
7\end{array}$ & $\begin{array}{l}5 \\
5\end{array}$ & $\begin{array}{l}9 \\
8\end{array}$ & $\mathrm{~V}$ & $\begin{array}{l}\mathrm{V} \\
\mathrm{V}\end{array}$ & $\begin{array}{l}\mathrm{V} \\
\mathrm{V}\end{array}$ & $\mathrm{V}$ & & & & & \\
\hline 4 & $\begin{array}{l}\text { Adi } \\
\text { Rozikin }\end{array}$ & $\begin{array}{l}5 \\
5\end{array}$ & $\begin{array}{l}4 \\
5\end{array}$ & $\begin{array}{l}3 \\
4\end{array}$ & $\begin{array}{l}\mathrm{V} \\
\mathrm{V}\end{array}$ & $\bar{V}$ & $\begin{array}{l}-- \\
--\end{array}$ & & $\mathrm{V}$ & $\begin{array}{l}\text { V } \\
\text { V }\end{array}$ & & & \\
\hline 5 & $\begin{array}{l}\text { Dewi } \\
\text { Winda }\end{array}$ & $\begin{array}{l}7 \\
6\end{array}$ & $\begin{array}{l}7 \\
6\end{array}$ & $\begin{array}{l}12 \\
8\end{array}$ & $\begin{array}{l}\mathrm{V} \\
\mathrm{V}\end{array}$ & $\begin{array}{l}\mathrm{V} \\
\mathrm{V}\end{array}$ & $\begin{array}{l}\mathrm{V} \\
\mathrm{V}\end{array}$ & & & & & & \\
\hline 6 & $\begin{array}{l}\text { Ayub } \\
\text { Agus }\end{array}$ & $\begin{array}{l}6 \\
5\end{array}$ & $\begin{array}{l}5 \\
8\end{array}$ & $\begin{array}{l}5 \\
5\end{array}$ & $\begin{array}{l}\mathrm{V} \\
\mathrm{V}\end{array}$ & $\begin{array}{l}\mathrm{V} \\
\mathrm{V}\end{array}$ & $\begin{array}{l}\mathrm{V} \\
\mathrm{V}\end{array}$ & & & & & & \\
\hline 7 & $\begin{array}{l}\text { Richo } \\
\text { Wawan }\end{array}$ & $\begin{array}{l}7 \\
4\end{array}$ & $\begin{array}{l}8 \\
7\end{array}$ & $\begin{array}{l}10 \\
8\end{array}$ & $\begin{array}{l}\mathrm{V} \\
-\end{array}$ & $\begin{array}{l}\text { V } \\
\text { V }\end{array}$ & $\begin{array}{l}\mathrm{V} \\
\mathrm{V}\end{array}$ & V & & & & & \\
\hline
\end{tabular}




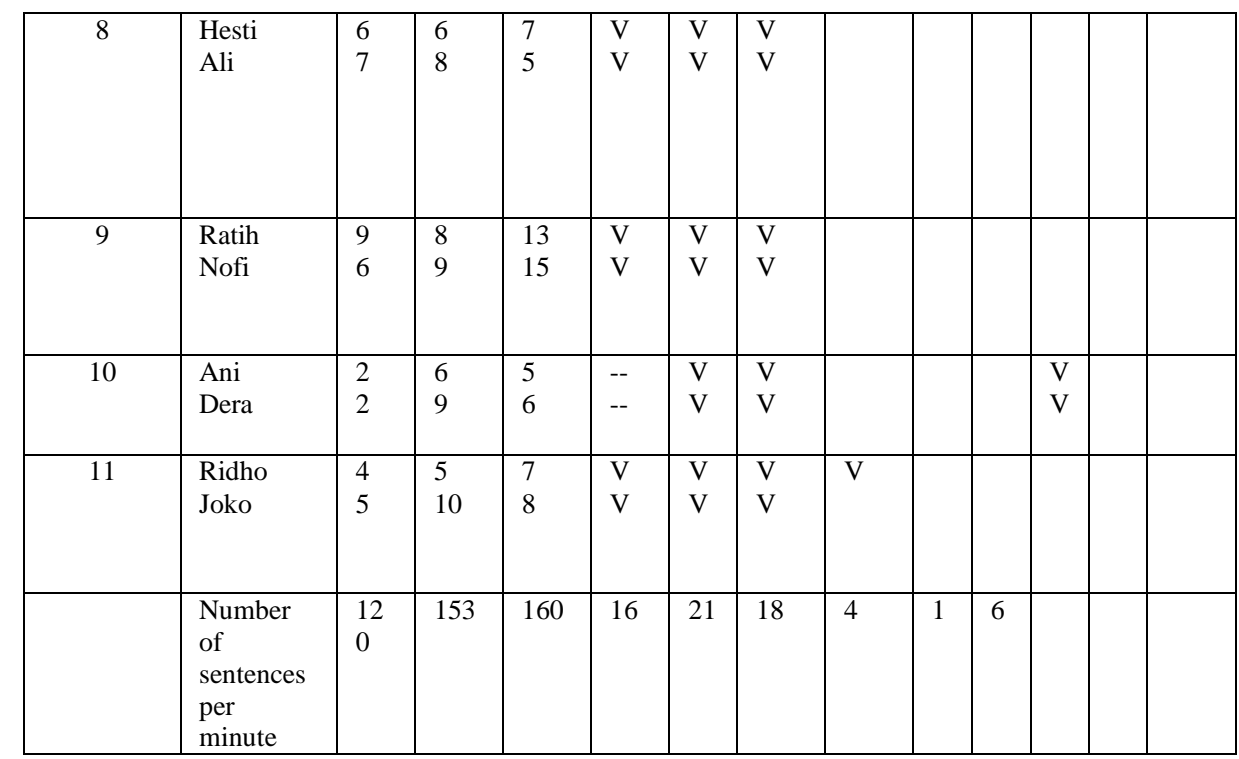

Surprisingly, Adi that was "active" on the first week degraded to "fair" on the second week. He was the only less active student in comparison with his other fellows, Ani, Dera and Hana.

On the whole, this the third week's presentation may be the best presentation during Cycle 2, if it is viewed on the total questions being collected. On the week, all students could manage better recording than that of the previous weeks, 160 sentences. Most contribution were supported by several students who could ask more than 7 sentences in one minute. More than that 3 students asked 8 questions, one student 9, 10, 11, 12, 13, and 15 respectively. Those questions were uttered without looking at their notebooks. On the week, however, there were 4 students could not maintain their best performances as their record showed "less" than the first and second week. 


\section{The analysis of questionaire}

By observing data of the students' performances on Cycle 1 and 2 on the table 4 , there were several findings. Those quantitative data was in line with the qualitative data as well as the teacher's daily observation in the classroom.

\section{Table 4}

The comparison of the result on cycle 1 and 2

\begin{tabular}{|l|l|l|l|l|l|l|l|l|l|}
\hline \multirow{2}{*}{ Cycle } & \multicolumn{2}{|l|}{ Active } & \multicolumn{2}{l|}{ Fair } & \multicolumn{2}{l|}{ Poor } \\
\cline { 2 - 10 } & \multicolumn{2}{|l|}{ Onward week } & \multicolumn{2}{l|}{ Onward week } & \multicolumn{3}{l|}{ Onward week } \\
\cline { 2 - 10 } & 1 st & 2nd & 3 rd & 1 st & 2nd & 3 rd & 1 st & 2nd & 3 rd \\
\hline $\begin{array}{l}\text { Cycle } \\
\%\end{array}$ & - & - & 2 & 4 & 7 & 6 & 18 & 12 & 14 \\
\hline$\%$ & 0 & 0 & 9 & 18 & 31,8 & 27,2 & 81,8 & 54,2 & 63,6 \\
\hline Cycle & 16 & 21 & 18 & 4 & 1 & 6 & - & & - \\
\hline$\%$ & 72,7 & 95 & 81,8 & 18 & 4,5 & 27,2 & 0 & 0 & 0 \\
\hline
\end{tabular}

On the first, second, and third week in Cycle 1 there were not any students who actively responded the game. Even the smart students getting good scores in the academic raport didn't talk much. That silence broke up at last on the third week by two male students.

Several students still felt doubtful on this "silent period". They might be on the period of learning a new concept: the game and its techniques of playing. Usually on this phase the students kept silent to wait until they were ready to make a response. It's not surprising that in the end two male students tried to be active. Male persons felt more confident than female, or male persons were extrovert and females introvert. 
On the contrary in Cycle 2, all students were active by giving positive responses. Starting from the first until second and third week, the percentage number of students belonged to the "active" category, rose $72 \%, 7 \%, 95 \%$, and $81,8 \%$ respectively. It was assumed that on this stage the students began to enjoy the game. The answer of the first question of the questionaire shows that $86 \%$ of the students had fun. The students admitted thet they got a reward during the play. The students' answer on the first question matched with the third question, they were interested in the learnin process.

Those above answers of students were not supported by the answers of questions 2, 4, and 5. The students complained with the teacher's technique of teaching in the classroom.

The answer of sixth question shows that the students got difficulties to raise question in the game. Contrastly, In the classroom activities, there were only 8 students (36\%) had problems of making questions because they were shy and a bit nervous. The rest of them, $64 \%$ could answer well.

When the questionaire (question no. 7) asked them whether something disturbed them on the process of the teaching, only 2 students answered "yes" because of being fooled down by other friends and 19 students found no difficulties to play the game.

Question no. 8 asked the students whether they got support from "other people", for example parents, relatives or close friends. $77 \%$ students answered "yes". Question no.9 asked them wether they liked English or not. $54 \%$ students answered that they did not like that subject. $46 \%$ answered that they like English because they need English to get job, it is International language and they want to be able to communicate with expatriates. 


\section{Conclusion and suggestion}

Based on the above research study, it was concluded that the application of the "Mystery Guest Game" in teaching English proved useful in enhancing the students English verbal communication of grade X-1 SMAN 1 Pabelan. Eventhough the students had poor performance in Cycle 1, they got significant improvement in Cycle 2. The teaching learning process recorded by a camera showed that the students responded positively: they reacted, shouted, laughed and clapped their hands to show enthusiasm.

That game was effective to increase the students' interest in learning English. The game provided the students competition, group work, and relax atmosphere that decreased students' anxieties. It contributed to the students confidences in communication.

Based on the conclusion, hence this finding is worth to all language practitioners, teachers and tutors. Any kinds of language games when they are managed well, they will contribute to language learning. In addition, this finding shows that games make students enjoy the class and encourage students to speak more productively. It is also wise to say that the school or education institutes should teach and facilitate their students to run language games in their curriculum or provide more references or educational software to develop this so good skills.

\section{References}

Arikunto, Suharsimi. Et all. 2006. Penelitian Tindakan Kelas. Jakarta: Penerbit Bumi Aksara.

Atmoyuwono,Siswadi. Et all. 1994. All About People: Basic I. Jakarta: Lembaga Bahasa LIA.

Brown, H.D. 2008. Prinsip Pembelajaran dan Pengajaran Bahasa. Jakarta:Kedutaan Besar Amerika. 